\title{
温度及触觉受体的发现及研究——浅析2021年诺贝尔 生理学或医学奖
}

潘学琪, 王瑞, 间致强

深圳湾实验室分子生理学研究所, 深圳 518107

*联系人, E-mail: zqyan@szbl.ac.cn

人类有 5 种感觉: 视觉、听觉、嗅觉、味觉、触觉, 此外 还有温觉(包括热觉和冷觉)、痛觉等. 历史发展的长河中, 人 体是如何感知物理世界的问题一直吸引着人类. 然而，人类 关于这些感觉的基础生物学层面的理解仍然十分有限. 2021 年诺贝尔生理学或医学奖授予感知觉研究领域, 以表彰美国 加州大学旧金山分校(University of California, San Francisco, UCSF)的David Julius和Scripps研究所的Ardem Patapoutian在 感知温度与触觉受体的发现上作出的深远而广泛的贡献. 其 中David Julius的工作主要集中于对温度觉受体的鉴定及分 子转导机制的研究, 他对TRPV1的发现及研究打开了从分子 水平理解温度感觉的大门; 而Ardem Patapoutian则主要集中 于对触觉受体的研究, 这些受体是我们感知及适应内外环境 变化的基础. 本文着重对本次诺贝尔生理学或医学奖进行解 读, 并简介其他感知觉受体的发现及研究历程.

\section{1 视觉、嗅觉、味觉的研究}

在感知觉研究的历史中, 视觉的研究发展较快. 1967年诺 贝尔生理学或医学奖颁发给美国科学家George Wald、Haldan K. Hartline及瑞典科学家Ragnar A. Granit, 以表彰三人发现了眼 睛的初级生理及化学视觉过程. 视觉研究进展较为迅速的一个 原因是光受体蛋白-视紫红质数量多, 此类蛋白有颜色标记, 容 易识别和获取. 随后则是嗅觉的研究. 1991年, 来自美国的科学 家Richard Axel和博士后Linda B. Buck的研究首次揭示了嗅觉受 体分子家族 ${ }^{[1]}$, 因此Richard Axel和Linda B. Buck共同于2004年获 得诺贝尔生理学奖. 人类有 5 种基本味觉，包括酸、甜、苦、 咸、鲜. 其中甜味和鲜味是由T1R1、T1R2和T1R3异二聚体介 导，苦味则可以激活 $\mathrm{T} 2 \mathrm{R}$ 受体，酸敏感细胞的特征性分子为 PKD2L1, 而感受碳酸的分子为CA IV, 咸味的感知部分与 EnaC 通道相关 ${ }^{[2]}$. 味觉受体能否获得诺贝尔奖, 值得期待与关注.

\section{2 温度觉受体的研究}

\subsection{David Julius-圧房中的科学家——热敏感离子 通道的发现}

对于植物天然产品的研究已被证明是鉴定和操纵疼痛

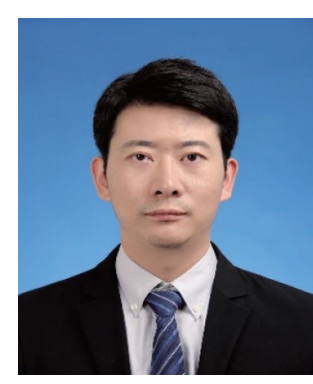

隊致强教授, 深圳湾实验室分子 生理学研究所资深研究员。致力于听 觉、触觉受体的鉴定和工作机理的 研究.

通路的关键元素的最强大和重要的工具之一. 两个著名的例 子是罂粟中的吗啡和柳树皮中的水杨酸盐(阿司匹林的前 体), 这些天然产品对疼痛的研究和治疗产生了深远影响, 直 至今天它们作为两类主要止痛药物而广为使用. 上述两种植 物的研究都是止痛相关的, 也有很多植物产物是致痛的. 辣 椒因为其独特的辛辣感而被世界各地在料理中广泛采用. 哺 乳类动物因为对辣椒素敏感，在野外排斥进食辣椒，而鸟类 则对辣椒素不敏感所以在进化上作为辣椒传播种子的载体 一定程度的辣椒素接触人的口腔和嘴唇等区域会引发出汗 和灼热感, 这一现象被称为味觉出汗.

热感觉受体的发现离不开辣椒素(capsaicin)的贡献. 辣椒 素是辣椒的活性成分, 我们平常在进食辛辣食物时会感觉到 灼热感. Caterina和Julius等人 ${ }^{[3]}$ 通过分离啮齿动物背根神经 节制备了cDNA文库, 用该文库转染辣椒素不敏感细胞, 最终 分离出一个基因, 同源比对表明它属于瞬时受体电位(transient receptor potential, TRP)阳离子通道超家族. Julius继续通 过异源细胞表达TRPV1受体，使用电生理技术对其进行功能 表征，发现辣椒素诱发的电生理特性类似于感觉神经元，同 时拮抗剂可以阻断电流. 在随后的研究中, Julius证明了其对 高温(高于 $40^{\circ} \mathrm{C}$ )的敏感性, 发现热能显著激活TRPV1并导致 细胞 $\mathrm{Ca}^{2+}$ 内流, 而超过 $40^{\circ} \mathrm{C}$ 的高温对人体来说已经起到伤害 作用了 ${ }^{[3]}$. 随后的研究发现, 基因敲除TRPV1后, 小鼠对于热 的急性反应出现了部分的缺失及不敏感 ${ }^{[4]}$. 对表达TRPV1的 神经纤维的研究发现, 其不在响应触觉、本体感觉等的感知 无害性刺激的 $\mathrm{A}$ 型神经元上表达, 而是在表达 $\mathrm{P}$ 物质、神经激 
肽 $\mathrm{A}$ 和CGRP的多肽能 $\mathrm{C}$ 型纤维上表达. TRPV1也随后作为一 种感知伤害性刺激的神经纤维的标志物而被领域内的科学 家们所广泛认可并采用. 后续的研究更发现, TRPV1除了直 接参与感知热痛, 也在热痛后的痛觉超敏、过敏反应以及在 痒觉信息的传导中也发挥了重要作用. 如当被蚊子叮咬而引 发组胺介导的过敏反应这一化学痒通路时，TRPV1就参与其 中 $^{[5,6]}$.

TRPV1在热感觉中起到关键作用, TRPV1是否为唯一的 热感觉受体呢? 2011年, Voets研究组 ${ }^{[7]}$ 在模式小鼠上确定 TRPM3 是除TRPV1以外的第二个热敏传感器，但TRPM3及 $T R P V I$ 双基因敲除小鼠中仍然会出现有害热反应. 因此, 2004年Julius再次注意到TRP通道家族成员TRPA1. TRPA1是 一种化学刺激感受器, 可以感受多种有害外部刺激, 如芥子 油、辣根、肉桂、大蒜、丁香和生姜中的活性化合物，以及 脂质化合物、环境刺激物和其他化学物质 ${ }^{[8]}$. TRPA1离子通 道不仅可以被化学物质激活，同时可以被冷和热激活，其激 活方式较为复杂 ${ }^{[9]}$. 由此可见, 在TRP家族中还存在除了 TRPV1以外的其他通道可作为热感觉传感器.

\section{2 冷感觉离子通道的发现}

人体在不同的环境中可以感知不同的温度, 上述研究发 现热感觉的受体, 对于冷感觉而言, Julius和Patapoutian实验 室 ${ }^{[10]}$ 于2002年发现了冷感觉受体TRPM8, 也属于TRP超家族 成员. 研究过程是将TRPM 8 过表达于异源细胞中, 给予细胞 无害寒冷的温度刺激, 利用电生理记录发现细胞出现电流变 化, 同样在TRPM8基因鄗除小鼠中也表现出对冷刺激感知的 缺陷 ${ }^{[11]}$. 由此可见TRPM8在冷感觉中发挥着重要作用.

\subsection{TRPV1在温暖感觉中的作用}

人类皮肤对温度变化的感知非常精确，感知的阈值约为 $1{ }^{\circ} \mathrm{C}^{[12]}$. 除了伤害热及冷感觉, 我们常常可以感觉到温暖舒 适. TRPV1最初被认为是有害热传感器, 对于无害热受体又 会是什么? 随后的研究发现，TRPV1也可以参与到无害热的 转导中 ${ }^{[13]}$. 此外, McNaughton实验室 ${ }^{[14]}$ 发现另一个TRP通道 家族成员TRPM 2 是一个潜在的无害热传感器. 由上述研究可 知，TRPV1、TRPA1、TRPM2和TRPM3离子通道共同承担 热感觉传感器作用, 而TRPM8则是唯一的冷感觉传感器. 因 此人体在区分冷热感觉时，依赖的是热敏感神经元及冷敏感 神经元的活动程度, 当含有 TRPV $1 、 T R P A 1 、 T R P M 2$ 和 TRPM3离子通道的神经元激活，同时表达TRPM8离子通道 的神经元活动受到抑制时, 才能可靠地感知温暖的感觉 ${ }^{[15]}$.

\section{4 温度觉受体与人类疾病的关系}

温度觉离子通道发挥如此重要的作用，当其出现突变时 会导致多种人类遗传性疾病, 被称为“TRP通道病”. 例如, 常 染色体显性TRPA1通道病是由 TRPA1基因点突变引起的, 临
床常表现为在寒冷、禁食和应激时出现上半身持续性疼 痛 ${ }^{[16]}$. 此外, TRPVI c. $1911 \mathrm{~A}>\mathrm{G}$ 与冷性痛觉减退相关 ${ }^{[17]}$.

总之, TRPV1作为辣椒素受体和热感觉离子通道的发现 打开了温度觉领域研究的大门, 代表了人类在探索热传感的 分子和神经基础方面的研究取得的里程碑式的成就. 未来的 研究可能会在这个领域提供更多的见解, 发现更多的温度觉 的受体. 在此基础上, Julius并不只满足于鉴定受体和通道的 功能性研究, 他和同事Yifan Cheng ${ }^{[18]}$ 通过冷冻电子显微镜解 析了TRPV1的结构, 将对该通道的理解带到了一个新的高度.

\section{Ardam Patapoutian-现实中的尤达大师 触觉受体的发现及研究}

\subsection{Piezo2作为触觉和本体感觉受体的发现}

在日常生活中，可以通过机械力的介导识别不同物体的 纹理、大小和形状, 以及感受自身的空间位置和肢体的运动, 这些看似平常的活动却受到精细的调节，涉及不同神经元的 独特功能. 触觉是日常生活中最常接触到的感觉之一. 从对 于手中事物的纹理形状重量等的静态感知，再到风抚过脸庞 和爱人之间的情感性触碰的动态感觉; 从感知蚊虫在身上爬 动到被锤子砸到手, 都在很大程度上依赖触觉对于机械力的 感知.

触觉主要通过皮肤这一人体最大的器官上的机械感觉 末端小体以及支配他们的低阈值的机械力受体(low threshold mechnoreceptor, LTMR)的组合所编码传递. 有毛的皮肤和无 毛的皮肤对于机械力的感知方式存在差异. 早期研究发现了 皮肤上有4种触觉受体(迈斯纳小体、默克尔细胞、帕西尼小 体和拉夫尼末梢) 以及支配这些受体对应的神经末梢, 其感受 范围各异, 对刺激的频率和持续时间敏感. 为了找到哺乳动 物中的机械敏感受体, 加利福尼亚州Scripps研究所的Patapoutian开发了一种新的篮选方法. 首先他与博士后Coste使用 压力针结合膜片钳的方法发现Neuro2A 细胞系具有机械敏感 性, 该细胞系给予压力刺激后会出现压力敏感电流 ${ }^{[19]}$. 随后 Patapoutian鉴定出 72 个可能作为机械力受体的候选基因, 最 后通过RNAi敲低每一个候选基因, 并利用压力针结合膜片 钳方法来确定给细胞施加机械力是否会产电流. 当敲低候选 基因FAM $38 A$ (之后的Piezol基因)后, 机械敏感电流消失, 证明 该蛋白具有机械敏感性，此后该蛋白从希腊语单词“piesi”中 得名, 命名为Piezo1. Patapoutian将Piezol 异源表达于HEK 293细胞中, 给细胞施加压力后, 产生了机械敏感电流. 随后 通过同源序列比对发现了第二个机械敏感通道, 命名为 Piezo2. 新发现的Piezo通道属于以前未知的蛋白质家族，该 蛋白存在于脊椎动物和很多真核生物中. 其中Piezo2主要表 达在背根神经节中, 并且Piezo2的敲低消除了这些感觉神经 元的机械敏感性 ${ }^{[19]}$.

以上的研究证明了Piezo具有机械敏感性, 但是否为触觉 
受体仍不得而知. 为了找到证明Piezo2 是触觉受体的直接证 据, 2014年, Patapoutian实验室 ${ }^{[20]}$ 证明在Merkel细胞中给予机 械刺激后出现机械力依赖的电流, 并且该电流可以导致下游 出现动作电位, 从而直接证明了Piezo2是真正的触觉受体, 2014年的另一项研究显示Piezo2基因敲除小鼠严重缺乏触 觉, 而不损害其他感觉 ${ }^{[21]}$, 从行为学上再次证明Piezo2 是触觉 受体. 另外Patapoutian实验室 ${ }^{[22]}$ 还证明Piezo2 是小鼠本体感 觉的主要受体, 因为Piezo2基因敲除小鼠会出现严重的运动 不协调及肢体位置觉异常.

Piezo蛋白是一类全新的脊椎动物机械敏感通道, 由 2500 个氨基酸组成, 是拥有 38 个跨膜结构域的最大跨膜离子通道 亚单位. Patapoutian和其他实验室的工作揭示了Piezo1和 Piezo2的高分辨率结构. Piezo蛋白为三聚体结构, 包括中心 离子通道和三个外围机械感应螺旋桨形叶片. 三个叶片向外 和向上弯曲, 在细胞膜表面形成纳米碗状结构. 当对膜施加 机械力时, 弯曲的叶片变平并导致中心孔的开放. 带有弯曲 叶片的螺旋桨状结构产生了较大的平面内膜面积, 这可能解 释了Piezo通道的机械敏感性 ${ }^{[23]}$.

\section{$3.2 P i e z 0$ 与人类疾病的关系}

Piezo通道在人体内多个器官中发挥着不可替代的作用. Patapoutian团队 ${ }^{[24]}$ 证明, 动脉压的维持主要依赖于迷走神经 和舌咽神经节中的Piezo1和Piezo2，双基因敲除小鼠表现血 压的波动. 在胃肠道中, 肠嗜铬细胞表达Piezo2, 该细胞通过 释放激素和旁分泌信号分子来响应来自胃肠道的机械刺 激 ${ }^{[25]}$. 此外, Piezo2也是尿路上皮细胞和膀胱感觉神经元的机 械感受器, 条件性Piezo2 基因敲除小鼠出现膀胱控制功能受 损 ${ }^{[26]}$.

Piezo2基因的突变是多种遗传性疾病的基础(导致多种 遗传疾病), 临床常表现为触觉、振动和本体感觉的缺失或下 降. 随着对Piezo2突变导致疾病的不断认识与扩大, 最终将 Piezo2突变导致的遗传病称为Piezo2缺乏综合征，此类患者 出现本体感觉、触觉显著减弱, 临床症状常表现为感觉性共 济失调、步态异常、辨距不良、肌肉无力萎缩、脊柱侧凸 畸形、髋关节发育不良和进行性骨骼挛缩，部分患者出现围 产期呼吸窘迫和排尿障碍 ${ }^{[27]}$.

总之, Piezo通道的发现为触觉的探索开辟了新的道路, 同时也为临床疾病治疗提供靶标.

\section{4 听觉受体的发现及研究}

听力是人类的主要感官之一, 但是听觉的研究进展缓慢, 尽管1961年诺贝尔生理学或医学奖就已经颁发给了 Georg von Bekesy, 但是在亚里士多德定义的5种感官中, 介导嗅 觉、味觉、视觉、触觉的受体已经相继被确定, 且嗅觉、触 觉均已拿到诺贝尔奖, 但是听觉受体及机械转导机制却一直 未知. 内耳中的Corti器中的毛细胞是感知声音的第一级神经 元, Corti器上有超过 16000 个毛细胞, 定位于其上的呈阶梯状 排列的毛细胞发束被认为是声电转导的重要部位. 基于内耳 的精密结构, 数量较少的毛细胞, 体外培养毛细胞的困难, 因 此听觉蛋白受体的确定较为曲折.

2002年, Andrew J. Griffith实验室和Karen P. Steel实验室 分别在先天性耳狵患者和耳袭小鼠模型身上发现同一个致 病基因 $T M C I^{[28,29]} .2011$ 年, Andrew J. Griffith实验室和Jeffrey R. Holt实验室合作研究发现在毛细胞中, 除 TMC1之外, TMC 家族同源分子 TMC2 在听觉转导过程中同样发挥重要作用, 只有在把 $T M C 1$ 和 $T M C 2$ 同时敲除的情况下, 才能完全消除毛 细胞的机械传导电流 ${ }^{[30]}$. 上述研究初步证明, TMC蛋白家族 可能是参与听觉机械转导的关键蛋白.

除TMC $1 / 2$ 之外, 其他一些分子对于毛细胞的机械传导 也很重要, Ulrich Mueller实验室发现的LHFPL5和TMIE也参 与毛细胞机械转导, 到底哪个分子是机械转导离子通道孔道 区核心亚基, 仍无定论. 2018年, Holt和Corey团队 ${ }^{[31]}$ 合作证明 $\mathrm{TMC} 1$ 蛋白可以形成二聚体, 并且预测 TMC1蛋白跨膜区 S4 S7结构域可能构成了毛细胞机械传导通道的孔道区. 而 真正证明 TMC 是机械力通道的成孔亚单位的研究来自问致 强团队及其合作者 ${ }^{[32]}$. 该研究将绿海龟的 TMC1 (CmTMC1) 与虎皮鹦鹉的TMC2(MuTMC2) 在昆虫细胞里表达并纯化, 再重构在脂质体里进行电生理记录, 证明了 $\mathrm{CmTMC} 1$ 和 MuTMC2蛋白均具备离子通道活性并可以被机械力激活 ${ }^{[32]}$, 最终人类听觉受体的谜团被揭开.

目前世界范围内约有 5 亿人患有听力损失. 另有研究表 明, 新生儿中耳狵疾病的发病率为 $1 \%$, 其中 $50 \%$ 左右与遗传 因素相关. 目前遗传性耳狵助听器和人工耳蜗植人是治疗感 觉神经性听觉丧失的主要方法, 但治疗结果存在高度的异质 性且无法恢复由听力影响带来的其他功能区域的损伤. 目前 听觉受体虽然已经被鉴定, 但是对于听觉受体机械转导的分 子机制有待进一步研究.

\section{推荐阅读文献}

1 Buck L, Axel R. A novel multigene family may encode odorant receptors: A molecular basis for odor recognition. Cell, 1991, 65: 175-187

2 Yarmolinsky D A, Zuker C S, Ryba N J P. Common sense about taste: From mammals to insects. Cell, 2009, 139: 234-244

3 Caterina M J, Schumacher M A, Tominaga M, et al. The capsaicin receptor: A heat-activated ion channel in the pain pathway. Nature, 1997, 389: 816-824

4 Caterina M J, Leffler A, Malmberg A B, et al. Impaired nociception and pain sensation in mice lacking the capsaicin receptor. Science, 2000, 288: 
306-313

5 Julius D. TRP channels and pain. Annu Rev Cell Dev Biol, 2013, 29: 355-384

6 Dong X, Dong X. Peripheral and central mechanisms of itch. Neuron, 2018, 98: 482-494

7 Vriens J, Owsianik G, Hofmann T, et al. TRPM3 is a nociceptor channel involved in the detection of noxious heat. Neuron, 2011, 70: 482-494

8 Bandell M, Story G M, Hwang S W, et al. Noxious cold ion channel trpa1 is activated by pungent compounds and bradykinin. Neuron, 2004, 41: 849-857

9 Laursen W J, Anderson E O, Hoffstaetter L J, et al. Species-specific temperature sensitivity of TRPA1. Temperature, 2015, 2: 214-226

10 McKemy D D, Neuhausser W M, Julius D. Identification of a cold receptor reveals a general role for TRP channels in thermosensation. Nature, 2002, 416: 52-58

11 Dhaka A, Murray A N, Mathur J, et al. TRPM8 is required for cold sensation in mice. Neuron, 2007, 54: 371-378

12 Stevens J C, Choo K K. Temperature sensitivity of the body surface over the life span. Somatosensy Motor Res, 1998, 15: 13-28

13 Yarmolinsky D A, Peng Y, Pogorzala L A, et al. Coding and plasticity in the mammalian thermosensory system. Neuron, 2016, 92: 1079-1092

14 Tan C H, McNaughton P A. The TRPM2 ion channel is required for sensitivity to warmth. Nature, 2016, 536: 460-463

15 Paricio-Montesinos R, Schwaller F, Udhayachandran A, et al. The sensory coding of warm perception. Neuron, 2020, 106: 830-841.e3

16 Kremeyer B, Lopera F, Cox J J, et al. A gain-of-function mutation in TRPA1 causes familial episodic pain syndrome. Neuron, 2010, 66: 671-680

17 Binder A, May D, Baron R, et al. Transient receptor potential channel polymorphisms are associated with the somatosensory function in neuropathic pain patients. PLoS ONE, 2011, 6: e17387

18 Zhang K, Julius D, Cheng Y. Structural snapshots of TRPV1 reveal mechanism of polymodal functionality. Cell, 2021, 184: 5138-5150.e12

19 Coste B, Mathur J, Schmidt M, et al. Piezo1 and Piezo2 are essential components of distinct mechanically activated cation channels. Science, 2010, 330: $55-60$

20 Ikeda R, Cha M, Ling J, et al. Merkel cells transduce and encode tactile stimuli to drive A $\beta$-afferent impulses. Cell, 2014, 157: 664-675

21 Ranade S S, Woo S H, Dubin A E, et al. Piezo2 is the major transducer of mechanical forces for touch sensation in mice. Nature, 2014, 516: 121125

22 Woo S H, Lukacs V, de Nooij J C, et al. Piezo2 is the principal mechanotransduction channel for proprioception. Nat Neurosci, 2015, 18: 17561762

23 Wang L, Zhou H, Zhang M, et al. Structure and mechanogating of the mammalian tactile channel PIEZO2. Nature, 2019, 573: 225-229

24 Zeng W Z, Marshall K L, Min S, et al. PIEZOs mediate neuronal sensing of blood pressure and the baroreceptor reflex. Science, 2018, 362: 464467

25 Alcaino C, Knutson K R, Treichel A J, et al. A population of gut epithelial enterochromaffin cells is mechanosensitive and requires Piezo2 to convert force into serotonin release. Proc Natl Acad Sci USA, 2018, 115: E7632-E7641

26 Marshall K L, Saade D, Ghitani N, et al. PIEZO2 in sensory neurons and urothelial cells coordinates urination. Nature, 2020, 588: 290-295

27 Chesler A T, Szczot M, Bharucha-Goebel D, et al. The role of PIEZO2 in human mechanosensation. N Engl J Med, 2016, 375: 1355-1364

28 Kurima K, Peters L M, Yang Y, et al. Dominant and recessive deafness caused by mutations of a novel gene, $T M C 1$, required for cochlear hair-cell function. Nat Genet, 2002, 30: 277-284

29 Vreugde S, Erven A, Kros C J, et al. Beethoven, a mouse model for dominant, progressive hearing loss DFNA36. Nat Genet, 2002, 30: 257-258

30 Kawashima Y, Géléoc G S G, Kurima K, et al. Mechanotransduction in mouse inner ear hair cells requires transmembrane channel-like genes. J Clin Invest, 2018, 121: 4796-4809

31 Pan B, Akyuz N, Liu X P, et al. TMC1 forms the pore of mechanosensory transduction channels in vertebrate inner ear hair cells. Neuron, 2018, 99: 736-753.e6

32 Jia Y, Zhao Y, Kusakizako T, et al. TMC1 and TMC2 proteins are pore-forming subunits of mechanosensitive ion channels. Neuron, 2019, 105: 310-321.e3 


\title{
Discovery of temperature and touch receptors: An introduction of the 2021 Nobel Prize in Physiology or Medicine
}

\author{
Xueqi Pan, Rui Wang \& Zhiqiang Yan* \\ Institute of Molecular Physiology, Shenzhen Bay Laboratory, Shenzhen 518107, China \\ *Corresponding author, E-mail: zqyan@szbl.ac.cn
}

Human has five senses, including vision, touch, hearing, taste, smell and taste, as well as temperature (including heat and cold) and pain sensation. How humans perceive the physical world through somatic sensation has fascinated us for centuries. The 2021 Nobel Prize in Physiology or Medicine was awarded to David Julius from the University of California, San Francisco (UCSF) and Ardem Patapoutian from Scripps Institute for their thermal and mechanical transducers discoveries.

David Julius pursued a project to identify the receptor for capsaicin in the late 1990s. He screened a cDNA library from rodent dorsal root ganglia, identified a cDNA encoding a novel ion channel belonging to the superfamily of transient receptor potential (TRP) cation channels (now called TRPV1). In subsequent studies, TRPV1 demonstrated a pronounced activation by heat (especially above $40^{\circ} \mathrm{C}$ ) and led to cellular calcium influx. Patch-clamp recordings revealed a heatevoked membrane current similar to those of sensory neurons. Furthermore, high temperatures above $40^{\circ} \mathrm{C}$ have already been harmful to the human body. Because mice lacking Trpv1 showed only a minor loss of acute noxious heat sensation, other heat-sensitive receptors must exist. In 2011, Voets and his team identified TRPM3 as a second heat-sensitive receptor. In 2004, Julius noticed TRPA1, another superfamily of transient receptor potential (TRP) cation channels, can be activated by various chemical substances, as well as by cold and heat. In 2002, Julius and Patapoutian identified TRPM8 and found it can be activated by low temperature, which humans perceive as innocuous cold. At present, important roles for TRPV1, TRPA1, TRPM3, and TRPM8 in temperature sensing have been experimentally established. Thus, the discovery of TRPV1 by David Julius opened the door and represented a landmark achievement to a molecular understanding of thermosensation. Future studies will likely provide additional insights into this active research field.

Ardem Patapoutian mainly focuses on the research of mechanosensitive ion channels. He identified a mechanosensitive Neuro2A cell line by using brief and rapid indentation of the plasma membrane in combination with patch-clamp recording. Ardem Patapoutian screened 72 candidate genes, including known ion channels and proteins of unknown function. The candidate genes were silenced by RNA interference one by one. Knockdown of the FAM38A, eliminated the mechanically activated current and the protein was named Piezo1. A second mechanosensitive channel Piezo2, was discovered by sequence homology. Piezo1 and Piezo2 represent an entirely novel class of ion channels as mechanical sensors. In 2014, Patapoutian found mice lacking Piezo2 in neither Merkel cells nor sensory neurons deficient in light touch sensation. Patapoutian also demonstrated that Piezo2 is the principal transduction channel for proprioception in mice. In further work, Patapoutian and his group found central roles of Piezo1 and Piezo2 for many physiological functions. The mutations in the Piezo2 gene cause several genetic disorders manifested by altered sensations of touch, vibration and proprioception in humans. The discovery of Piezo proteins provides insights into how humans perceive internal and external environments. This review focuses on the 2021 Nobel Prize in Physiology or Medicine. Recent other research on sensory perceptions is also briefly introduced.

Nobel Prize in Physiology or Medicine, temperature sensation, touch, TRPV1, Piezo

doi: 10.1360/TB-2021-1252 